\title{
A Test of an Indirect Method for Censusing Shorebirds in Intertidal Habitats
}

\author{
J. J. Thompson*
}

\begin{abstract}
An indirect method for censusing shorebirds is described which uses a marker species of known abundance to gauge the abundance of other species on tidal flats at low tide. Shorebirds were censused using the indirect method at Yatsu tidal flat, Tokyo Bay, and the counts compared with estimates derived from total scan counts. The generally close agreement between the two methods suggests that the indirect method may be a useful alternative method for censusing shorebirds, particularly when the intertidal areas are large and when few people are available to conduct the censuses.
\end{abstract}

\section{Introduction}

An indirect census method has recently been described that can be used for censusing shorebirds (Thompson 1992). The method is especially suited for large intertidal areas when there are only few people available to conduct censuses. The method was originally developed for Australian conditions where some species of shorebirds roost at high tide in mangrove trees, or at dispersed locations that may be difficult to locate. Similar conditions occur in Japan, with shorebirds often widely dispersed in reclaimed areas at high tide. Yatsu tidal flat, near Tokyo, Chiba Prefecture $\left(35^{\circ} 40^{\prime} \mathrm{N} 140^{\circ} 01^{\prime} \mathrm{E}\right)$, is an ideal location to test the indirect method. It is small enough that a "total count" of all birds at low tide is possible (Ishikawa and Kuwabara 1983), yet large enough to validly use the indirect method.

\section{Methods}

A full description and analysis of the assumptions and limitations of the indirect method is given by Thompson (1992). The method is applied by using a marker species of known abundance to gauge the abundance of other species on tidal flats at low tide. It is essential that the abundance of the marker species can be estimated relatively accurately, either at roosts or on the feeding grounds at low tide. Moreover, the marker species must be relatively abundant and comprise a significant proportion of the birds present. The abundance of the marker species is used to gauge the number $\left(N_{x}\right)$ of each other species according to the formula

$$
N_{x}=\frac{N_{m} \times P_{x}}{P_{m}}
$$

where $N_{m}$ equals the total number of the marker species present in the area covered by the

Received 18 May 1992; Revised 30 July 1992; Accepted 3 August 1992.

* Japan Wildlife Research Center, 29-3, Yushima 2-chome, Bunkyo-ku, Tokyo, 113.

Author's current address: 20 Bredden Street, Chapel Hill 4069, Brisbane, Queensland, Australia. 
census, $P_{x}$ equals the percentage on the feeding grounds of the species to be estimated and $P_{m}$ equals the percentage of the marker species on the feeding grounds. This equation is similar to typical mark-recapture formulae (Seber 1982). $P_{x}$ and $P_{m}$ are estimated by repeatedly scanning the tidal flats at low tide and counting the number of each species observed. This is best done by recording data into a hand-held tape recorder. In general, the more scans that are made, the more accurate the population estimates will be. Unlike other low tide census methods, it does not matter if the same individual bird is counted more than once during the scan counts.

Yatsu tidal flat is small (approximately $50 \mathrm{ha}$ ) but approaching the maximum area that can be censused using a single scan from a fixed location. A total count of all species was made from a fixed location with the incoming tide, but before birds began departing for high tide roosting sites. It was assumed that the estimates from the total count method were perfectly accurate. A second set of counts was made by repeatedly scanning small sections of the tidal flat and recording the number of each species into a hand-held tape recorder. Yatsu is accessible on three sides so the repeated scans were made from several vantage points surrounding the tidal flat. The results from the scan counts were later transcribed from the tape recordings, the total number counted of each species tallied, and the relative abundance (percentage) of each species calculated from the summed totals. Separate censuses were conducted on 1 September and 21 October 1991.

The Grey Plover (Pluvialis squatarola) was used as the marker species because it was one of the most abundant species and was easy to identify and count accurately. The European and Australian Curlew (Numenius arquata, Numenius madagascariensis) and Large and Mongolian Sandplovers (Charadrius leschenaultii, Charadrius mongolus) were grouped together for these analyses since there was insufficient time to positively distinguish all individuals in the field. Since Large Sandplovers rarely occur at Yatsu tidal flat (Kuwabara pers. comm.), all sandplovers were assumed to be Mongolian Sandplovers.

\section{Results}

Results from the two censuses are given in Table 1. For each census, results from the total count method and indirect census method are compared in two ways; the absolute (numerical) difference in abundance for each species and the difference expressed as a percentage of the total count estimate. In general, the less abundant species tended to have the greatest percentage deviation from the total count estimates, but the smallest difference in terms of absolute numbers. Conversely, abundant species had the smallest percentage deviations, but the largest differences in absolute numbers. The greatest discrepancy in total numbers occurred in the October census, when the indirect method underestimated the total number of Dunlins (Calidris alpina) by 61 birds. The largest percent variation occurred in October, when the indirect method underestimated the number of Lesser Golden Plovers (Pluvialis fulva) and Great Knot (Calidris tenuirostris) by $75 \%$.

The percentage deviation could not be calculated for the Greenshank (Tringa nebularia) in the September count because this species was seen during the scan counts for the indirect method, but not during the total count. 
Table 1. Comparisons of estimates derived from the indirect and total count census methods on 1 September (a) and 21 October (b) 1991.

(a)

\begin{tabular}{|c|c|c|c|c|c|c|}
\hline Species & $\begin{array}{l}\text { Number } \\
\text { counted } \\
\text { low tide }\end{array}$ & $\%$ & $\begin{array}{l}\text { Indirect } \\
\text { method } \\
\text { estimate }\end{array}$ & $\begin{array}{l}\text { Total } \\
\text { scan } \\
\text { count } \\
\text { estimate }\end{array}$ & $\begin{array}{l}\text { Absolute } \\
\text { difference } \\
\text { between } \\
\text { estimates }\end{array}$ & $\begin{array}{c}\text { Percent } \\
\text { difference } \\
\text { between } \\
\text { estimates }\end{array}$ \\
\hline Charadrius alexandrinus & 423 & 41.3 & 273 & 287 & 14 & 4.9 \\
\hline Charadrius mongolus & 60 & 5.9 & 39 & 51 & 12 & 23.5 \\
\hline Pluvialis fulva & 0 & 0 & 0 & 0 & - & - \\
\hline Pluvialis squatarola & 400 & 39.1 & 258 & 258 & 0 & 0 \\
\hline Calidris ruficollis & 29 & 2.8 & 19 & 16 & 3 & 18.8 \\
\hline Calidris acuminata & 0 & 0 & 0 & 0 & - & - \\
\hline Calidris alpina & 4 & 0.4 & 3 & 3 & 0 & 0 \\
\hline Calidris canutus & 0 & 0 & 0 & 0 & - & - \\
\hline Calidris tenuirostris & 0 & 0 & 0 & 0 & - & - \\
\hline Crocethia alba & 10 & 1.0 & 6 & 10 & 4 & 40.0 \\
\hline Tringa nebularia & 1 & 0.1 & 1 & 0 & 1 & - \\
\hline Tringa brevipes & 69 & 6.7 & 45 & 29 & 16 & 55.2 \\
\hline Xenus cinereus & 7 & 0.7 & 5 & 3 & 2 & 66.7 \\
\hline Limosa limosa & 0 & 0 & 0 & 0 & - & - \\
\hline Limosa lapponica & 8 & 0.8 & 5 & 4 & 1 & 25.0 \\
\hline $\begin{array}{l}\text { Numenius } \\
\quad \text { arquata/madagascariensis }\end{array}$ & 5 & 0.5 & 3 & 2 & 1 & 50.0 \\
\hline Numenius phaeopus & 7 & 0.7 & 5 & 6 & 1 & 16.7 \\
\hline Total & 1023 & 100 & 662 & 660 & & \\
\hline
\end{tabular}

(b)

\begin{tabular}{|c|c|c|c|c|c|c|}
\hline Species & $\begin{array}{l}\text { Number } \\
\text { counted } \\
\text { low tide }\end{array}$ & $\%$ & $\begin{array}{l}\text { Indirect } \\
\text { method } \\
\text { estimate }\end{array}$ & $\begin{array}{l}\text { Total } \\
\text { scan } \\
\text { count } \\
\text { estimate }\end{array}$ & $\begin{array}{c}\text { Absolute } \\
\text { difference } \\
\text { between } \\
\text { estimates }\end{array}$ & $\begin{array}{c}\text { Percent } \\
\text { difference } \\
\text { between } \\
\text { estimates }\end{array}$ \\
\hline Charadrius alexandrinus & 329 & 22.1 & 266 & 264 & 2 & 0.8 \\
\hline Charadrius mongolus & 9 & 0.6 & 7 & 18 & 11 & 61.1 \\
\hline Pluvialis fulva & 2 & 0.1 & 1 & 4 & 3 & 75.0 \\
\hline Pluvialis squatarola & 305 & 20.5 & 247 & 247 & 0 & 0 \\
\hline Calidris ruficollis & 27 & 1.8 & 22 & 29 & 7 & 24.1 \\
\hline Calidris acuminata & 2 & 0.1 & 1 & 2 & 1 & 50.0 \\
\hline Calidris alpina & 771 & 51.8 & 624 & 685 & 61 & 8.9 \\
\hline Calidris canutus & 8 & 0.5 & 6 & 9 & 3 & 33.3 \\
\hline Calidris tenuirostris & 3 & 0.2 & 2 & 8 & 6 & 75.0 \\
\hline Crocethia alba & 0 & 0 & 0 & 0 & - & - \\
\hline Tringa nebularia & 4 & 0.3 & 4 & 7 & 3 & 42.9 \\
\hline Tringa brevipes & 0 & 0 & 0 & 0 & - & - \\
\hline Xenus cinereus & 0 & 0 & 0 & 0 & - & - \\
\hline Limosa limosa & 4 & 0.3 & 4 & 4 & 0 & 0 \\
\hline Limosa lapponica & 19 & 1.3 & 16 & 15 & 1 & 6.7 \\
\hline $\begin{array}{l}\text { Numenius } \\
\quad \text { arquata/madagascariensis }\end{array}$ & 4 & 0.3 & 4 & 3 & 1 & $\begin{array}{c}33.3 \\
-\end{array}$ \\
\hline Numenius phaeopus & 0 & 0 & 0 & 0 & - & - \\
\hline Total & 1487 & 100 & 1204 & 1295 & & \\
\hline
\end{tabular}




\section{Discussion}

Although there was generally close agreement between the results from the two methods, the usefulness of the indirect census method depends, in part, on the accuracy acceptable to the investigator. For the purposes of some, the underestimate of $75 \%$ for Lesser Golden Plovers and Great Knots in October may be unacceptably high. Others may think this unimportant considering the small difference between the two estimates in terms of absolute numbers (a difference of two and six birds respectively). Therefore, the investigator must decide whether to use the indirect method according to the level of precision required and the availability of more accurate methods.

An advantage of the method is that low tide censuses can be performed at any stage of the tide, even at low tide when birds are dispersed over large areas. This is not always possible with other methods since low tide censuses often have to be made when shorebirds are being concentrated into a small area by the flooding tide, and counts must be completed quickly before birds begin departing for roosting sites. It is easy to make mistakes in these hurried conditions, particularly if birds are constantly moving between feeding patches. Moreover, other methods may be affected if birds are disturbed by the presence of the observer and fly ahead of the census direction to be counted more than once.

This study has assumed that the total scan count was perfectly accurate. However, it would be unusual if this was really the case. Even at a small site such as Yatsu, errors with the total scan count method occur if (a) there are unseen movements of birds within the study area while the birds are being counted (b) there are unseen movements of birds into, and out of, the study area during counting (c) the census taker experiences fatigue during counting. In the September count, for example, the Greenshank was recorded using the indirect method but not when the total scan count method was used. This illustrated how uncommon species can be detected more easily using the indirect method because scans can be performed more systematically. However, the general agreement between results from the two methods in the present study suggested that problems of unseen bird movement or observer fatigue were not serious at Yatsu.

A limitation of the indirect method is that during the Japanese winter, species such as the Dunlin form large, tightly-packed flocks on the tidal flats and tend not to mix with other species (Ozaki pers. comm.). This habit would reduce the method's accuracy because unispecific aggregations bias census results if scan counts do not cover the entire tidal flat evenly. One solution to this problem is to make a separate count of the aggregating species, and use the indirect method only for the remaining species. Another disadvantage of the method is that it is tedious. Making continuous counts of birds, recording data into a tape recorder and later transcribing it may appeal only to the most devoted wader-watchers. However, at sites with large tidal flats and few people available for conducting the census, there may be few other ways of counting shorebirds. In such cases, the indirect method may be a useful alternative and can verify estimates derived from other methods. 


\section{Acknowledgments}

This work was conducted under a Science and Technology Agency Fellowship of the Government of Japan. I wish to thank Mr K. Kuwabara and two anonymous referees for suggesting improvements to this paper.

\section{References}

Ishikawa, T. \& Kuwabara, K. 1983. Changes in numbers of plovers at Yatsu tidal flat. Strix 2: 19-32.

Seber, G. A. F. 1982. The estimation of animal abundance and related parameters (2nd edition). Charles Griffin and Co., London.

Thompson, J. J. 1992. Spatial and temporal patterns of shorebird habitat utilisation in Moreton Bay, Queensland. PhD thesis, University of Queensland, Australia.

\section{潮間帯に生息するシギ・チドリ類個体数の間接調査法の有効性検査}

本報で述べるシギ・チドリ類個体数の間接的調査法は, 個体数の判明している種を, 干潮時の干潟に生 息する他の種の個体数を測る指標種にし, 調查する方法である。この調査法の有効性を検証するために, 東 京湾谷津干潟で, 間接調査法と従来の全個体数カウント法でシギ・チドリ類をカウントし, 両方法による カウント值を比較した。その結果, 両値は㧍拈む权近似した值となった。間接調查法は, とりわけ潮間帯の 面積が大きく, 調査人数が少ない場合に効果的であり, シギ・チドリ類の有用な調查法であることが示さ れた。

Thompson, J. J.: 財）自然環境研究センター客員研究員

現住所, 77 頁脚注に記載. 